\title{
RETROSPECTIVE ANALYSIS OF PUBLISHED HYDROLOGICAL RESEARCHES: MODELS, TRENDS AND GEOGRAPHICAL ASPECTS OVER THE LAST TWO DECADES OF HYDROLOGICAL MODELLING
}

\author{
David Honek, Martin Caletka, Monika Šulc Michalková* \\ * Masaryk University, Faculty of Science, Department of Geography, Kotlářská 2, 602 00, Brno, Czech Republic, \\ 324439@mail.muni.cz, martin.caletka@mail.muni.cz, sulc@mail.muni.cz
}

\begin{abstract}
Retrospective analysis of published hydrological researches: models, trends and geographical aspects over the last two decades of hydrological modelling

The expanding knowledge of natural processes, increasing computing capacity and demands related to the current environmental changes has resulted in more complex and a greater number of hydrological models. The amount of papers or studies has been rising sharply, especially over the last two decades. To understand the evolution, we statistically analysed papers involving the field of hydrological modelling. We explored the records of the SCOPUS web database for the time period of 1998 2017. Nearly 760 publications were identified. First, we compared the number of the papers to determine trends of their production. In the analysis, we focused on the classification of pre-defined factors - authorship, geographic origin, and the spatial and temporal scales of every model. We also conducted cluster analysis to highlight possible links between the individual models and the above-mentioned factors. The analysis of the data shows significant changes in the methodology applied iFn hydrological research as a result of the growing data availability, new sources of information and the importance of global research endeavours. Our findings highlight the increasing quantity and internationalization in the field.
\end{abstract}

Key words: hydrological modelling, models, review, publications, statistical analysis

\section{INTRODUCTION}

Hydrological modelling can be defined as a package of tools to solve and describe the behaviour of the hydrological cycle, including the repeat simulations of real processes in unreal temporal, spatial, environmental and social-economic conditions (Makel and Turbek 2008). A considerable number of studies involving hydrological modelling are published in numerous journals, such as Journal of Hydrology, Hydrological Processes, Hydrology and Earth System Sciences but also journals as diverse as Journal of the American Water Resources Association, Advances in Water Resources, Science of The Total Environment, Physics and Chemistry of the Earth, Climatic Change and Environmental Modelling and Software. The published papers take advantage of diverse spatial scales (catchment - state/ regional - continental/planetary) and temporal scales (minute/hour - day/week month/year - period). To characterize the actual state of hydrologic research, it is important to describe the evolution of quantity, themes and used models. Partial analyses have occurred in several papers.

Bízek et al. (2011) presented a brief overview of hydrological modelling as a suitable tool for water management and environment control. The wide range of possible applications of hydrological modelling was mentioned, together with the list of suitable hydrological models with detailed information of each model. They 
also described how to sort models through several classifications based on a) the purpose of application, b) the type of simulated system, c) the simulated hydrological process, d) the principle of cause and consequence, and e) the rate of temporal and spatial discretization. Pechlivanidis et al. (2011) mentioned the calibration approaches and uncertainty analysis of hydrological models to reveal and discuss relative advantages and limitations of each type of model. The "model set up" should be a part of all papers dealing with the application of any model, and Pechlivanidis et al. (2011) presented summary of different methods to quantify uncertainty in the model's predictions that could sit well within a model evaluation framework and highlighted the recent developments in hydrological modelling together with the list of the most used models. Most review papers bring only the listing of chosen models with a basic description and traditional model classification; however, some trend analysis of the field development has been neglected. An example of broader statistical analysis can be found in Salvadore et al. (2015), where the future directions of hydrological modelling in urbanized areas were presented. The paper exposed the current and future main topics and theses in urban hydrology, a list of 43 appropriate models with examples of applications and emphasized the challenges of the field itself.

The rapid progress of hydrological modelling during the last three decades has been mentioned by Beven (2001), Lindenschmidt et al. (2005), Silberstein (2006) and Roudier et al. (2015). Pechlivanidis et al. (2011) claimed that the hydrologic community has devoted considerable effort to understanding existing hydrological systems in pursuit of more accurate and powerful models during the past few years. The computational power has been strongly increasing since the beginning of the 21 th century, corresponding to improved methods and an increasing amount of hydrological models and Salvadore et al. (2015) added the important role of spatiallydistributed digital data. Additionally, hydrological modelling has become a whole field in itself, strengthening its position among the sciences. As observed by Kizza et al. (2011), Beven (2012), and Hailegeorgis and Alfredsen (2015), and continuing with e.g. Emam et al. (2015), Jie et al. (2016), Szolgay et al. (2016) and Zeng et al. (2016), hydrological modelling is the ability to solve and describe the hydrological cycle thanks to an innumerable range of methods and tools, and simulate the real processes in artificial conditions of temporal and spatial scales together with environmental, social and economic (present and future) changes, with the capability to repeat calculations. The definition by Szolgay in Makel and Turbek (2008) presents a hydrological model as an abstract or material implemented system used for simulating the hydrological characteristics of water bodies and processes and is capable of substitution in the process of attaining knowledge. According to Wheater et al. (2008) and Gayathri et al. (2015), a hydrological model is a simplification of a real world system, used mainly for the prediction of hydrological processes and based on variables such as rainfall, drainage area (topography), soil properties, vegetation cover, and runoff models and can be defined as a set of equations that enables the estimation of runoff as a function of various parameters used for describing watershed characteristics.

Thanks to new technologies in the 21th century (e.g., PC, radar and UAV), flood research has been expanded, taking advantage of knowledge in the fields of evapotranspiration, snow cover, etc., and new topics have been revealed. According to Lindenschmidt et al. (2005) and Sangati et al. (2009), floods have become more dangerous, notwithstanding the better predictions and protective systems, and 
Furusho et al. (2013) noted the problem of suburban rivers and the increasing risk of floods (using ISBA-TOPMODEL). For example, flash floods are very dangerous and hardly predictable, and have been investigated more often in recent papers (Collier 2007, Zanon et al. 2010, Coustau et al. 2012 and Pekárová and Miklánek 2014). The influence of climatic and environmental changes on floods has been discussed frequently since the year 2000 (e.g., Tague and Band 2001, Danihlík et al. 2004, Alfieri et al. 2011 and Szolgayová et al. 2014). In Kočický et al. (2008), Wheater and Evans (2009) and Pechlivanidis et al. (2011), land use and land cover changes are linked to climate change, socio-economic drivers, fires and ecosystem dynamics, and quantification of the effect of land use change on the catchment's hydrological response has long been an area of interest for the hydrological community. The effect of such processes on human activities has been discussed many times, e.g., the issue of freshwater supply for cities, lower agricultural yields, etc. (e.g., Kovář et al. 2001, Schneiderman et al. 2007, Jha and Gassman 2014 and Guse et al. 2015). Salvadore et al. (2015) mentioned the increase in importance of urban hydrology related to the growing concern about water sustainability and human health protection. SWAT model and SCS-CN method have often been used in such research endeavours, sometimes in combination with other models (e.g., GWLF in Schneiderman et al. 2007). Of course, many environments have been changing, and this topic has been discussed more often in many papers dealing with water ecosystems (river fauna and flora), water pollution (mainly phosphorus), river construction projects (dams, polders and others - e.g., Benjankar et al. 2011, Goebel et al. 2012 and Buchanan et al. 2013). In some cases, it was necessary to develop a new hydrological model based on the unique local conditions, e.g., CASiMiR (Benjankar et al. 2011) and SDDH-VSA (Goebel et al. 2012). Additionally, snow cover has been discussed and solved in specific models (e.g., ALPINE3D) with application in unique testing areas (mountain and sub-glaciers zones). The vast majority of snow cover research has been conducted in European and North American mountains (e.g., Lehning et al. 2006, Hlavčová et al. 2007, Alaoui et al. 2014 and Parajka et al. 2018). Hughes (2009), Nunes et al. (2009), and Garambois et al. (2013) published such studies, simulating the amount of surface and groundwater, predicting future development in these areas and presenting new models (MEFIDIS, Pitman, MARINE, etc.).

Calibration, validation and verification of models, followed by quantification and representation of uncertainty in hydrological modelling, are an integral part of the modelling process to find out a better model structure together with an improvement of model aspect and model parameters. That's why the majority of papers employ more than one model (the most common combinations are SWAT, MIKE SHE or VIC with other models), which means the consideration of the different model's outcomes for better results (e.g., Danihlík et al. 2004, El-Nasr et al. 2005, Schneiderman et al. 2007 and Viney et al. 2009). These papers presented descriptions of the entire water cycle (on or beneath the surface) of the catchment and sometimes only determined differences among models. A large portion of the papers, taking advantage of one model, have tested a new model or parameters (e.g., Daňhelka et al. 2003, Cho and Olivera 2009 and Hernández et al. 2012) or explored fundamental elements of the water cycle (e.g., Su et al. 2000, Lehning et al. 2006 and Al-Hamdan et al. 2015). Kovář and Nachtnebel (1996) mentioned increasing interest in the use of GIS for hydrological modelling (pre-processing and evaluating of datasets, modelling and result visualization). Šinka et al. (2015) char- 
acterized GIS as a suitable tool for the management, actualization and access of large amounts of data. Nevertheless, GIS-based models represent only one part of the field, and models based on fluid hydraulics constitute a second part.

Each model is unique, provides typical results and fits best for a defined purpose. Therefore, it is critical to choose an appropriate hydrological model or combination of models. Kizza et al. (2011), Beven (2012) and Emam et al. (2015) presented hydrological models as useful tools to guide decision making of problems related to water resource planning, flood forecasting, hydrological design and impact studies of climate change and land-use change. Hydrological models may be sorted according to several aspects. To many authors (e.g., Yevjevich 1987, Becker and Serban 1990, Beven et al. 1995, Beven, 2001, Bízek et al. 2011 and Unucka 2014) and also the World Meteorological Organisation (WMO), hydrological modelling involves decisions of basic philosophy on whether a model should be lumped or distributed, deterministic or stochastic, and conceptual, empirical or physical.

Stochastic models calculate the probable occurrence of a given value at a particular point. The hydrologic process is defined along with a discussion of the tendency, periodicity and stochasticity in the hydrologic series (Yevjevich 1987, Beven 2001 and Unucka 2014). In contrast, deterministic models are models in which outcomes are precisely determined through known relationships among states and events, without random variation. Deterministic models are more often used in hydrological research than stochastic models, and these models are divided into groups - conceptual, physical and empirical (Beven 2001, Bízek et al. 2011 and Unucka, 2014).

Conceptual models reflect physical laws in a simplified form, containing empirical derived relationships. These models suppress a space component, supposing changes of state parameters in concrete representative points (Becker and Serban 1990, Kulhavý and Kovář 2002 etc.). Physical models are based on fundamental physical laws (e.g., conservation of matter, energy and momentum; Darcy's laws) together with knowledge of hydrodynamics, thermodynamics, chemistry and biology (Becker and Serban 1990, Daňhelka et al. 2003 etc.). Empirical models are the simplest, depending on data representing the relationship between input and output series. All processes of the system are hidden in the model (Bízek et al. 2011 and Unucka 2014).

Another frequently presented classification for hydrological models is based on space discretisation, partitioning models into lumped, distributed and semidistributed models (Bízek et al. 2011 and Unucka 2014). In lumped models, a catchment is a single entity (or a small number of entities, such as reservoirs), and such models can simulate state variables and fluxes into and out of the catchment as a whole. Distributed models divide the original catchment into many entities (small representative parts) and the state variables and fluxes among the entities are defined across the catchment. Semi-distributed models are a combination of lumped and distributed models, dividing a catchment into hydrotops (small elementary catchments with some homogenous parameters, e.g., soil type, vegetation cover, etc.).

Based on the above-mentioned studies, it is evident that hydrological modelling has rapidly changed over the last two decades. This paper is focused on providing an overview of the geographic and temporal trends in hydrological modelling be- 
tween 1998 and 2017, and documenting the models used in published studies. We focused on the SCOPUS web database which contained the majority of the cited papers. We statistically and critically analysed almost 760 published papers, in which 119 models were found. No detailed analysis of this evolution had been previously conducted, and as such, we formulated the main aims of this paper as follows:

- to quantify in detail the evolution of the hydrological modelling,

- to identify the global centres and scientific teams with predominant publishing activity in the field,

- to evaluate the changes in both the spatial and temporal complexity of the research in which hydrological models have been employed,

- to assess the variability in hydrological models and determine the most frequently types used through the study period,

- in light of the characteristics of the aforementioned models, to verify, whether there are certain links between the individual models manifested by clusters.

\section{MATERIALS AND METHODS}

We first identified papers involving hydrological modelling in the Scopus electronic web database between 1998 and 2017 by using two simple keywords: "hydrology" and "model". Nearly 17,000 papers concerning flooding, modelling of river and catchment processes, including sediment transport, landscape denudation and other related topics were found. Using pre-defined filters (Environmental Science + Earth and Planetary Sciences + hydrological modelling + hydrological models + hydrological modelling), we identified 2,925 papers for subsequent searching. We looked through these papers and ultimately chose 756 items focusing on modelling of rainfall-runoff processes and containing the required information for the following statistical processing. The big number of rejected papers dealt with biological, chemical, social, politic and economic modelling, and to a lesser extent with hydrological modelling, or were not available on the websites.

Our trend analysis was similarly based on the classification used in Piégay et al. (2015). We examined the selected papers, and for each paper, we noted the title, the journal's name, the year of publication, the first author's name and country of origin, the international cooperation, the location of the study site, and the information based on the Tab. 1. In specific cases, it was difficult to determine the correct spatial and temporal classification of a paper. We analysed the main topics and theses in chosen 756 articles to reveal the subject matter of hydrological modelling.

According to Piégay et al. (2015), we explored the temporal evolution of authorship (number of authors and author's origin), journals, and both temporal and spatial scales from their annual frequency. We also determined a trend coefficient $R$ (correlation coefficients between the annual frequency of a given parameter and the year) for each paper. We also found out the temporal evolution of the diversity and the equitability using the two Shannon's indexes, $H$ and $E_{H}$ (O'Neil et al. 1988), with $p_{i}$ representing the frequency of the $i$-th nationality (among $S$ nationalities).

$$
H=\sum_{i=1}^{S} p_{i} \ln \left(p_{i}\right)
$$




$$
E_{H}=\frac{H}{\ln S}
$$

Shannon's indexes are used to quantify diversity in groups and to understand the groups' structure. The index $H$, represented by a value greater than 0 , is used to characterize the diversity of types in a group. A higher value of the $H$ index expresses a wider range of types within the group. The $E_{H}$ index represents the equitability of the group and assumes a value between 0 and 1 , with 1 corresponding to complete evenness (e.g., one representative for each type in the group).

\section{Tab. 1. Characteristics recorded for each paper reviewed}

\begin{tabular}{|c|c|}
\hline \multicolumn{2}{|l|}{ Temporal scale: } \\
\hline Event & $\begin{array}{l}\text { the papers deal with studies of one concrete situation (e.g., flood } \\
\text { reconstruction) }\end{array}$ \\
\hline Prediction & $\begin{array}{l}\text { the papers deal with the modelling of the future hydrologic progression } \\
\text { in the study site }\end{array}$ \\
\hline Other & remaining papers of the temporal classification \\
\hline \multicolumn{2}{|l|}{ Spatial scale: } \\
\hline Locality & $\begin{array}{l}\text { the study site is a small and specific research area (e.g., urban site, research } \\
\text { station surrounding) }\end{array}$ \\
\hline Catchment & $\begin{array}{l}\text { the papers deal with studies of one particular catchment with many rivers } \\
\text { or reservoirs }\end{array}$ \\
\hline Region & $\begin{array}{l}\text { the papers deal with studies of pre-defined area (e.g., particular state, karstic } \\
\text { system, two and more catchments in the same region) }\end{array}$ \\
\hline Transregion & $\begin{array}{l}\text { the papers deal with studies of large area (e.g., entire continent, more than } \\
\text { one state) }\end{array}$ \\
\hline
\end{tabular}

Determination of the models was complicated, requiring that we carefully read at least the section involving the materials and applied methods. Three hundred and seventy one models (or GIS tools) were found in 756 papers. This is a tremendous number of models which were applied in various researches across the world. We focused only on models used more than twice in all papers. Two hundred and fifty two models were presented only once in the papers, focusing on special research or new technics and approaches, e.g., ALPINE model for mountainous regions. These models were frequently based on older models to improve the applicability through the new opportunities of the hydrological research and fast evolution of the IT technologies (PC, UAV, radar etc.). The resultant list of 119 hydrological models is shown in Tab. 2. The classification of the models shown in Tab. 2 was based on a review of published papers and their documentation, together with information from the model-producer's website. In the next step, we constructed a database of rows (corresponding to the remaining papers) and columns (corresponding to the models recorded, with each considered as present (1) or absent (0)), which was analysed together with the chosen paper's information. 
Tab. 2. The list of applied models in chosen papers

\begin{tabular}{|c|c|c|c|c|c|c|c|c|c|c|c|c|c|c|c|c|}
\hline Model & $\mathrm{D}$ & $\mathrm{S}$ & $\mathrm{C}$ & $\mathrm{P}$ & E & $\mathrm{L}$ & $\mathrm{D}$ & $\mathrm{SD}$ & Year & MIKE 21 & - & • & & & • & $1990 \mathrm{~s}$ \\
\hline ACRU & $\cdot$ & & $\cdot$ & & & • & $\cdot$ & $\bullet$ & 1970 s & MIKE SHE & • & & • & & • & $1980 \mathrm{~s}$ \\
\hline ADAPT & • & & • & & & & & - & 1987 & MODCOU & - & - & & & - & 1984 \\
\hline AGWA & $\cdot$ & & • & & & & • & & 2002 & MODFLOW & • & & • & & • & 1988 \\
\hline ANN & & - & • & • & & • & & & 2010 & MOHYSE & - & - & & • & & 2007 \\
\hline ARW & & $\cdot$ & & $\cdot$ & & & • & & 2003 & MORDOR & • & - & & • & & $1990 \mathrm{~s}$ \\
\hline AWBM & $\cdot$ & & • & $\cdot$ & & $\cdot$ & & & 1993 & MOUSE & • & & • & • & & $1990 \mathrm{~s}$ \\
\hline BASINS & $\cdot$ & & & $\cdot$ & & & & • & 1996 & MPI-HM & - & & • & & • & 2003 \\
\hline CATHY & • & & & • & & & • & & 2009 & NAM & - & - & & - & & $1990 \mathrm{~s}$ \\
\hline CREST & $\cdot$ & & & • & & & • & & 2011 & NICE & - & • & & & • & $2000 \mathrm{~s}$ \\
\hline CRHM & • & & & • & & & & • & 2007 & ParFlow & - & & • & & - & $2000 \mathrm{~s}$ \\
\hline DBH & • & & & • & & - & - & & 2006 & ParFlow-CLM & - & & - & & - & $2000 \mathrm{~s}$ \\
\hline DHSVM & $\cdot$ & & & $\cdot$ & & & $\cdot$ & & 2004 & PCR-GLOBWB & - & • & & & • & 2009 \\
\hline DiCaSM & • & & • & & & & - & & 1997 & PDM & - & - & - & & - & 1985 \\
\hline DRAINMOD & $\cdot$ & & $\cdot$ & & & $\cdot$ & & & 1978 & PERSiST & - & & • & & • & - \\
\hline ECOMAG & $\cdot$ & & & • & & & • & & 1997 & PREVAH & • & - & & & • & 1999 \\
\hline G2G & $\cdot$ & & & $\cdot$ & & & • & & $2000 \mathrm{~s}$ & PRMS & • & • & & & $\cdot$ & 1983 \\
\hline GBHM & $\cdot$ & & & $\cdot$ & & & • & & 1998 & PROMET & • & & • & & - & $1990 \mathrm{~s}$ \\
\hline GEOtop & • & & • & & & & • & & 2004 & RHESSys & • & • & & & • & $1990 \mathrm{~s}$ \\
\hline GR2M & $\cdot$ & & $\cdot$ & & & $\cdot$ & & & 1989 & Rive-2D & • & & • & & - & 2002 \\
\hline GR4J & $\cdot$ & & $\cdot$ & & & • & & & 1999 & SAC-SMA & - & - & - & • & & 1973 \\
\hline GSM-SOCONT & $\cdot$ & & $\cdot$ & & & & & • & 2005 & SCS-CN & $\bullet$ & & • & $\cdot$ & $\cdot \cdot$ & 1956 \\
\hline GSSHA & • & & & • & & & - & & 2002 & SHETRAN & - & & - & & - & 1995 \\
\hline GWLF & $\cdot$ & & $\cdot$ & & & $\cdot$ & $\cdot$ & - & 1987 & SCHEME & • & & $\cdot$ & • & & - \\
\hline H08 & $\cdot$ & & $\cdot$ & $\cdot$ & & & • & & 2008 & SIMHYD & • & - & & - & & 2005 \\
\hline $\mathrm{HBV}$ & $\cdot$ & & $\cdot$ & & & • & & & 1976 & SLURP & - & • & & & • & $1990 \mathrm{~s}$ \\
\hline HEC-HMS & $\cdot$ & & $\cdot$ & & & • & • & • & $1990 \mathrm{~s}$ & SMAR & • & • & & • & & 1992 \\
\hline HEC-RAS & $\cdot$ & & & $\cdot$ & & & • & & $1990 \mathrm{~s}$ & SPARROW & • & • & & $\cdot$ & & 1997 \\
\hline HL-RDHM & $\cdot$ & & $\cdot$ & & & & - & & 1995 & STREAM & • & - & - & & - & 1999 \\
\hline Hqsim & $\cdot$ & & $\cdot$ & & & & & - & 1996 & SUPERFLEX & • & - & & & - & - \\
\hline HSAMI & $\cdot$ & & $\cdot$ & & & $\cdot$ & & & 2000 & SURFEX & - & & • & $\cdot$ & & - \\
\hline HSPF & $\cdot$ & & $\cdot$ & & & & & • & 1997 & SWAP & • & & $\cdot$ & $\cdot$ & & 2003 \\
\hline HYCYMODEL & $\cdot$ & & $\cdot$ & & & $\cdot$ & & & 1986 & SWAT & $\bullet$ & • & $\cdot$ & & • & 1986 \\
\hline HydroFlow & $\cdot$ & & $\cdot$ & & & & - & & 2012 & SWIM & • & & • & & • & $1990 \mathrm{~s}$ \\
\hline HydroGeoSphere & $\cdot$ & & & $\cdot$ & & & • & & $2000 \mathrm{~s}$ & SWMM & • & & • & & - & 1969 \\
\hline Hydrotel & $\cdot$ & & $\cdot$ & & & & • & & 2001 & TANK & - & • & & • & & 1979 \\
\hline HYDRUS & $\cdot$ & & $\cdot$ & & & & & • & $1990 \mathrm{~s}$ & TETIS & - & - & & & - & - \\
\hline HYDRUS-1D & $\cdot$ & & $\cdot$ & & & & & $\bullet$ & $1990 \mathrm{~s}$ & TOPKAPI & $\bullet$ & & $\bullet$ & & • & 1995 \\
\hline HYDRUS-2D & $\cdot$ & & $\cdot$ & & & & & • & $1990 \mathrm{~s}$ & TOPLATS & • & & $\bullet$ & & - & 1994 \\
\hline HYMOD & $\cdot$ & & $\cdot$ & & & $\cdot$ & & & 2001 & TOPMODEL & - & & • & & • & 1995 \\
\hline Hype & • & & • & & & & & • & 2008 & TopNet & - & & • & & - & 2001 \\
\hline HySIM & $\cdot$ & & $\cdot$ & & & $\cdot$ & & & 1977 & TOPURBAN & • & & • & & • & 1998 \\
\hline IHACRES & $\cdot$ & & $\cdot$ & & & & & • & 1997 & tRIBS & - & & • & & • & 2004 \\
\hline INCA & • & & $\cdot$ & & & & & • & 1990 & UHP & • & • & & & • & 2004 \\
\hline InHM & $\cdot$ & & & • & & & - & & 1999 & Vflow & - & & • & & - & 2004 \\
\hline InVEST & $\cdot$ & & & $\cdot$ & & & & • & 2014 & VHM & • & • & & $\cdot$ & & 2014 \\
\hline ISBA & $\cdot$ & & & $\cdot$ & & & • & & 1989 & VIC & - & • & & & • & 2004 \\
\hline $\mathrm{J} 2000$ & • & & & • & & • & & & 1997 & W3RA & - & & - & & - & 2010 \\
\hline KINEROS & $\cdot$ & & & $\cdot$ & & & • & & $1990 \mathrm{~s}$ & WaSiM-ETH & • & & • & & • & 1999 \\
\hline KINEROS2 & $\cdot$ & & & $\cdot$ & & & • & & $1990 \mathrm{~s}$ & WASMOD-D & • & • & & $\cdot$ & & 1996 \\
\hline Lascam & $\cdot$ & & $\cdot$ & & & $\cdot$ & & & 1996 & WaterGAP & - & - & & & - & 1999 \\
\hline LEW & • & & • & & & & & • & 2006 & WaterGAP3 & - & - & & & • & 1999 \\
\hline LISFLOOD & • & & & - & & & - & & 1999 & WATFLOOD & & - & & & - & 1993 \\
\hline
\end{tabular}




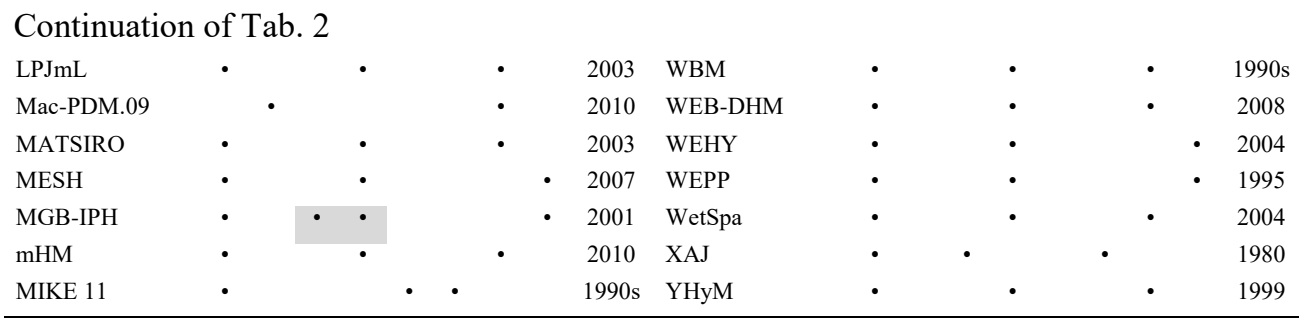

Note: D - deterministic; S - stochastic; C - conceptual; P - physical; E - empirical; L - lumped; D - distributed; SD - semidistributed.

Grey highlights - variable models' classification due to their parallel affiliation with different model categories (resulting from the models' development and adaptations to different purposes).

In the final step, we took advantage of the chosen information from papers to conduct statistical analyses on the dataset using the programming language $\mathrm{R}$ for sorting the hydrological models into clusters using the hierarchical clustering method. Based upon the analysis by Piégay et al. (2015), we used the procedure introduced by Chavent et al. (2012), namely, the ascendant clustering algorithm. The method is based on the homogeneity criterion, which corresponds to the sum of correlation ratios to a systematic variable that summarizes the variables in each cluster as accurately as possible (Piégay et al. 2015). In our case, the clustering method was based on 999 applications of 119 chosen models, because several models were used more than twice in investigated papers. The cluster analysis permits us to reveal possible relationships between the hydrological models and their characteristics with regard to the separation into clusters. Moreover, it is possible to assess the significance of the models' characteristics on different levels of the clustering.

\section{RESULTS}

\section{Geographical aspect}

The first authors of the papers incorporated into our research were based in 50 different countries, of which the 20 most frequent are listed in Fig. 1. Authors from these countries produced nearly $91 \%$ of all papers. The greatest number of works come from the USA (23\%), followed by Canada (10\%), Germany $(10 \%)$ and China $(10 \%)$. The other countries' participation is less than $5 \%$ each. Of the 4 dominating countries, all show a decreasing trend, excluding China $(\mathrm{R}=+0.89)$. From a global perspective, the major production comes from the USA and Canada (together accounting for $43 \%$ of papers), followed by European countries (39\%), among which Germany (10\%), the United Kingdom (4\%) and the Netherlands $(4 \%)$ have the highest contributions. Asian countries only account for approximately $12 \%$ of the global production. The dominant countries are China (10\%), Japan and India (2\% each). Australia and New Zealand account for less than $5 \%$ of the papers. Such low percentages of paper production is probably related to the relatively small number of applicable rivers in these countries. The remaining areas, including Africa (1\%) and Latin America (2\%), produced the lowest proportion $(3 \%)$ of the papers. A quite significant decrease has been recorded in the currently leading countries, namely, USA and Canada $(\mathrm{R}=-0.57)$. Simultaneously, papers' production has been increasing, especially in Asia $(\mathrm{R}=+0.58)$, and Latin America $(\mathrm{R}=+0.61)$, which is confirmed by balanced papers' production of anglophone 
and non-anglophone countries. Fig. 2 points to the contrast between the country of origin of the papers' first author and the location of the published research. The study areas are located across the entire world, mainly in North America, western Europe and south-eastern Asia. Africa is often discussed in papers (especially central Africa - the area of the Upper Nile), however only a small number of authors come from this area.

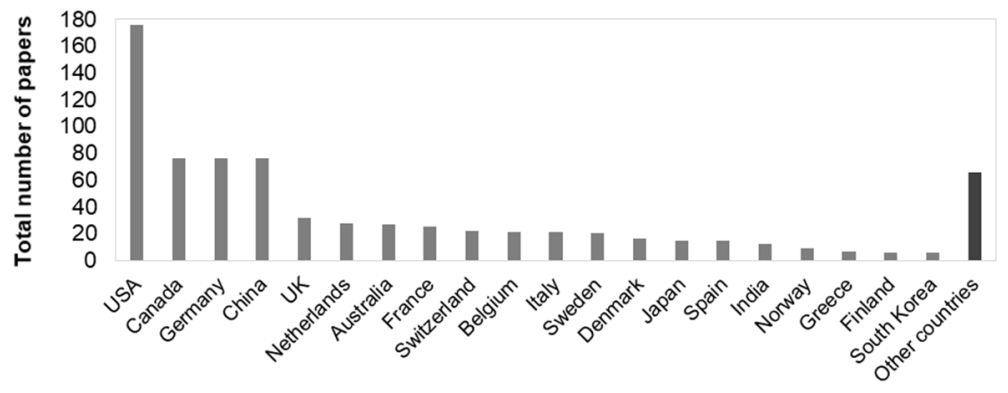

Fig. 1. First twenty countries by nationality of the papers' first author. Total number of chosen hydrological papers published in the Scopus web-database between 1998 and 2017.

Through the analysed period, transnational co-publication exhibited an increasing trend. These papers account for more than one third of all the papers of interest. However, a significant decrease was recorded in 2003 and 2005, when a substantial portion of the published papers came from the USA and European countries (e.g., Germany, Belgium, and the UK). We examined both US and European legislation and funding programmes, from which the research might have been financed to determine a reasonable explanation for these two discrepancies in the overall trend. However, no sufficient explanation was identified.

Growing values of the Shannon Index $\mathrm{H}$ validates the above-mentioned trends. As provided in Fig. 3A, the number of first author' nationalities together with the research's location doubled over the investigated period. The Shannon Index $E_{H}$ indicates the stable distribution of paper production among countries, nevertheless the locations of the hydrological research are relatively more variable. Fig. 3B shows that $E_{H}$ increased slightly for both. An obvious decrease of both indexes was recorded in 2005, which corresponds to the above-mentioned decrease in transnational co-publication in 2005. In 1998, all of the chosen papers were written by authors from one country (Canada). The authorship (number of authors) increased dramatically from 1998 (Fig. 4), but the equitability of authorship was stable over time (one article per capita). The temporal evolution of journals followed an ascendant evolution until 2007; meanwhile, the equitability decreased and fluctuated over the investigated time (gradual increase in the number of utilized journals). 

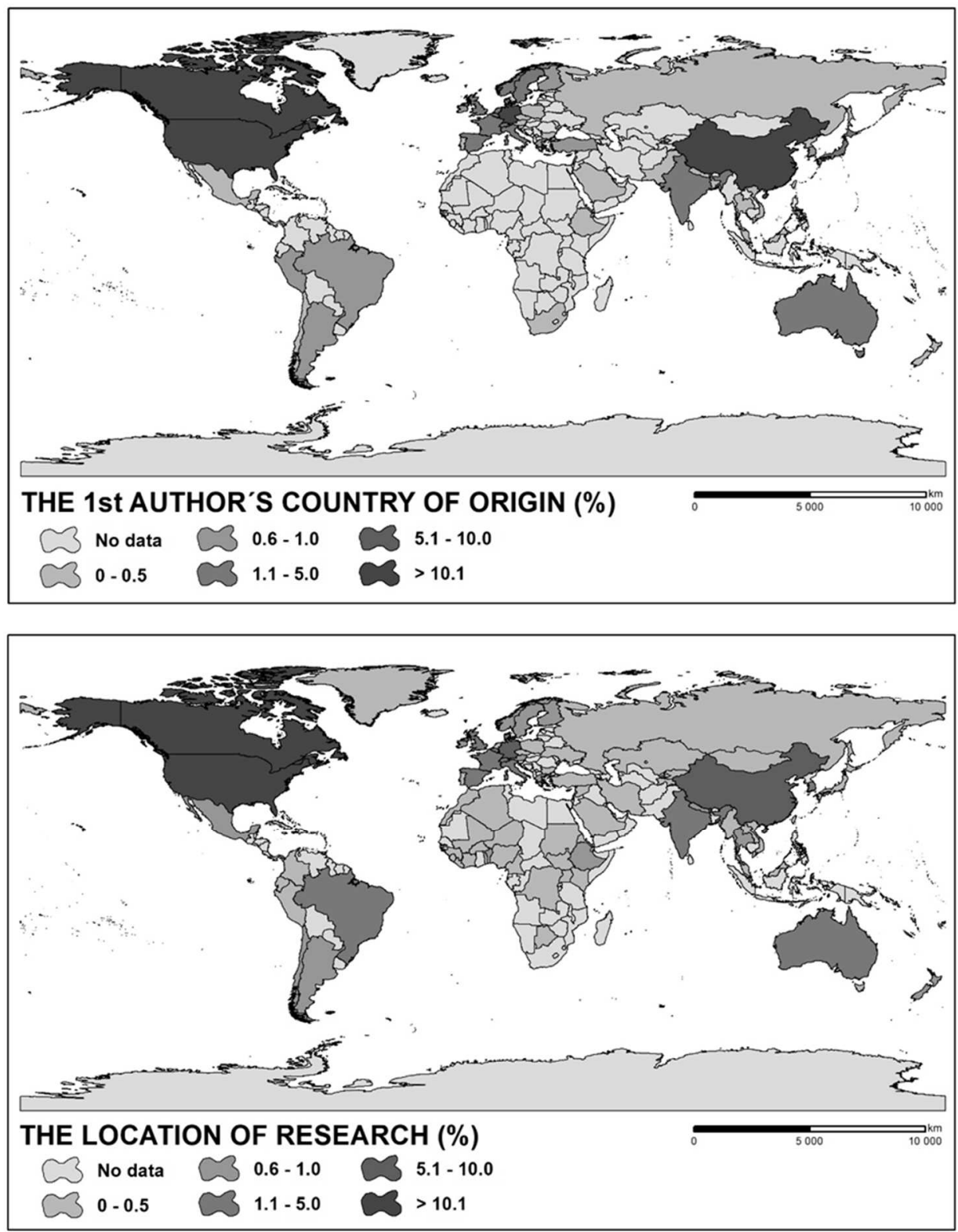

Fig. 2. The world map of the first authors' country of origin together with the location of published research on Scopus web-database during the time period 1998 to 2017 

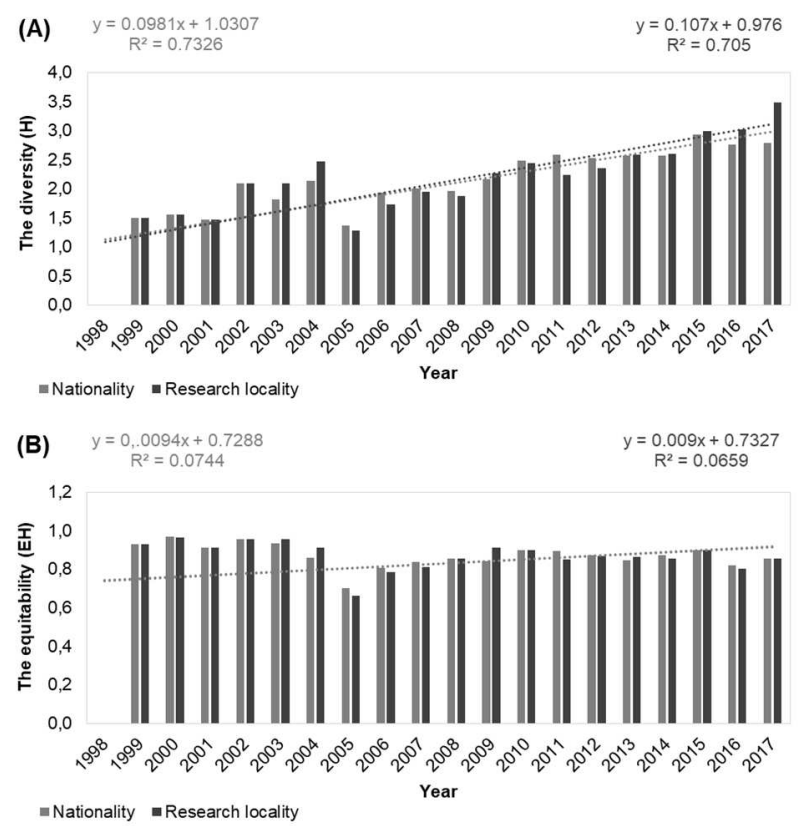

Fig. 3. Temporal evolution of the nationality of the first author and the research's location of chosen hydrological papers published in the Scopus web-database between 1998 and 2017, expressed as the Shannon Index. (A) The diversity $(H)$. (B) The equitability $\left(E_{H}\right)$.

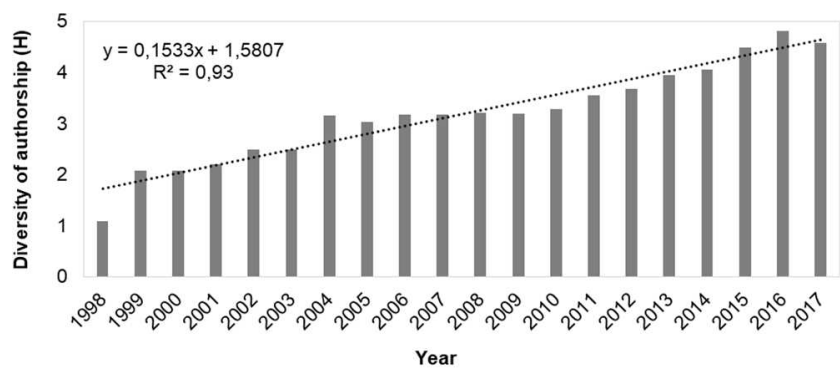

Fig. 4. Temporal evolution of the authorship of chosen hydrological papers published in the Scopus web-database between 1998 and 2017, expressed as the Shannon Index of diversity $(H)$

\section{Spatial and temporal complexity of research}

In terms of temporal scale, $63 \%$ of the investigated papers were concerned with the category Other, 36\% with Prediction and only 1\% with Event. Fig. 5 shows the trend of timescale groups. It is quite obvious that the category Other slowly decreased over time, which is related to the rising trend of Prediction. However, this trend turned around during the last five years. Only a minor portion of the papers applied hydrological models for the category Event. 
As for the spatial scale, studies most frequently focused on the scale Region (50\%), followed by Catchment (36\%), Transregion (8\%) and Locality $(6 \%)$. Trends of all groups fluctuated, however, papers involving the Transregion spatial scale increased from 2003 (Fig. 6), which could be related to the increasing transnational co-publication trend. Correlation coefficients reveal great differences between the scales. A rising trend was recorded for the Locality $(R=+0.62)$ and Transregion $(R=+0.64)$ scales. The reverse trend was observed for the Region $(R$ $=-0.37)$ and Catchment $(R=-0.11)$ scales. In light of these findings, scientists have been increasingly concerned with cross-boundary hydrological research on regional scales $\left(100 \mathrm{~km}^{2}-1000 \mathrm{~km}^{2}\right)$.

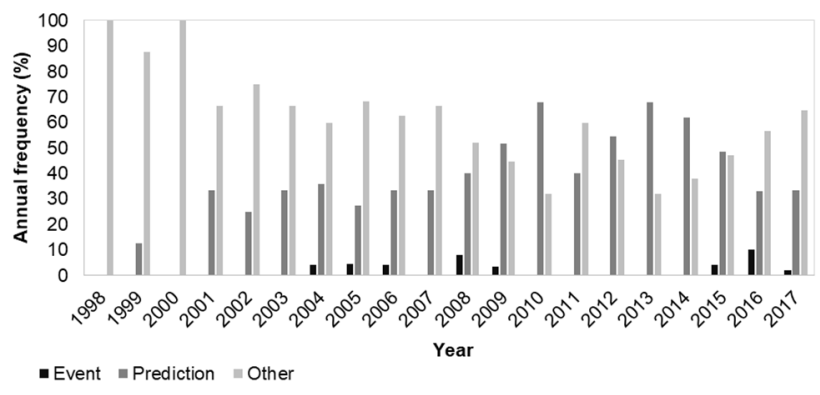

Fig. 5. Annual frequency (in \%) of the time scales covered in chosen hydrological papers published in the Scopus web-database between 1998 and 2017

Finally, we assessed the independence among all parameters using t-tests. Correlations seemed to exist between the amount of published papers, authorships, first author nationalities, journals and transnational co-publications. Nevertheless, our results show dependence only between the amount of published papers and authorship $(p<0.05)$, and nationalities, journals and transnational co-publications $(p<$ $0.005)$. No connection was found between the $E H s, E_{H}$ and $H$ indexes $(p<0.05)$, however, there is relevant dependence among $H$ indexes $(p<0.005)$ as we had previously hypothesized.

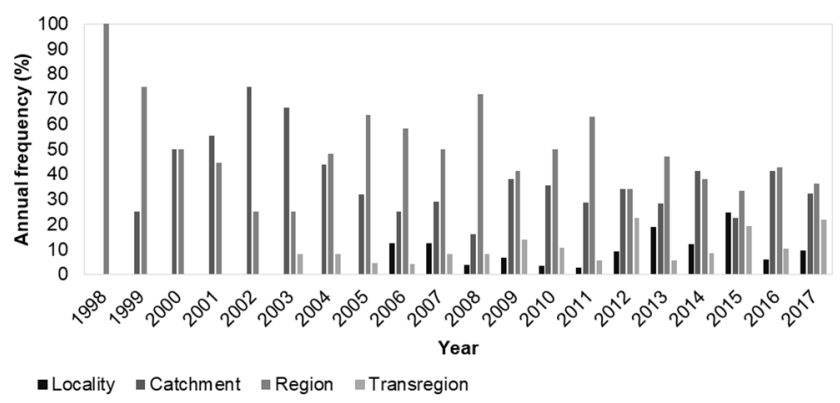

Fig. 6. Annual frequency (in \%) of the spatial scales covered in chosen hydrological papers published in the Scopus web-database between 1998 and 2017 


\section{Most frequent journals}

Qualitative analysis has revealed 3 journals with the greatest number of papers concerning hydrological models - Hydrological Processes (HP - 185 papers, i.e., 24.8\%), Journal of Hydrology (JH - 138, 18.5\%) and Hydrology and Earth System Science (HESS - 96, 12.9\%). All together, they account for $56.2 \%$ of the papers of interest here. A journal's significance among other scientific periodicals is expressed by impact factor (IF). It represents the rate at which an average article in a particular journal has been cited within a defined year or period. The IF values are ordinarily noted on the journals' web pages. HESS showed the highest IF (4.437), followed by the JH (3.483) and HP (3.014) - valid February 21th 2018).

The similar objective of these three journals is to publish original scientific and technical papers in all the subfields of the hydrological sciences and to improve our understanding of hydrological processes. The scope of published papers encompasses disciplines focusing on the physical, biogeochemical, mathematical and methodological aspects of hydrological processes together with research on social science perspectives on hydrological problems such as resource and ecological economics, environmental sociology, psychology and behavioural science, management and policy analysis, as well as sustainable management of water resources, water quality and water-related natural hazards. Therefore, journals have the ambition to serve, not only the community of hydrologists, but all earth and life scientists, water engineers and water managers etc.

\section{Subject matter of published research}

Three main topics of published researches have been identified - Hydrological modelling, Environment alteration and Model development (Fig. 7). The Hydrological modelling deals with the fundamental hydrological tasks, taking advantage of primary hydrological functions and interactions in the study areas. The first main topic of this group is to understand the basic hydrologic cycle in the study area together with catchment behaviour and stream flow responsibility. Beighley et al. (2005) describe the water cycle through the distribution of dominant runoff form and behaviour, which is useful for interpreting functions of runoff in the recruitment and transport of sediment and other contaminants. Butts et al. (2014) developed a dynamically coupled climate-hydrology system to evaluate the simulations of water cycle against measured climate variables, energy fluxes and flows. Flood research is the second main topic and the research can be separated into flood and flash flood research, dealing mainly with reconstructions of known flood events to develop flood forecasting system and appropriate model accessories. An example of this kind of the research was published by, e.g., Sharif et al. (2006), Collier (2007), Zanon et al. (2010) and Fares et al. (2014). The last subject matter of this group is eco-hydrology, which connects hydrological and biological research to investigate the ecosystem behaviour in stream flow and catchment environment. Tague and Band (2001), Goebel et al. (2012) and Whitehead et al. (2014) presented such oriented research.

The second main topic is the Environment alteration which investigates changes of the water cycle under climate, land use and land cover changes forced by human activities and disturbances. Nunes et al. (2009) or Jha and Gassman (2014) discussed the impact of climate change on the precipitation, moisture content and 
evapotranspiration on the study sites. Land use and land cover changes together with human activities (agriculture, urbanization, etc.) and strongly affect the environment, especially deforestation and urban constructions. Bormann et al. (2009), Maalim et al. (2013) and Badar et al. (2013) described the importance of human activities, the need for the understanding of their impact on catchment conditions, which can lead to inevitable disturbances of the total ecosystem and water budget.

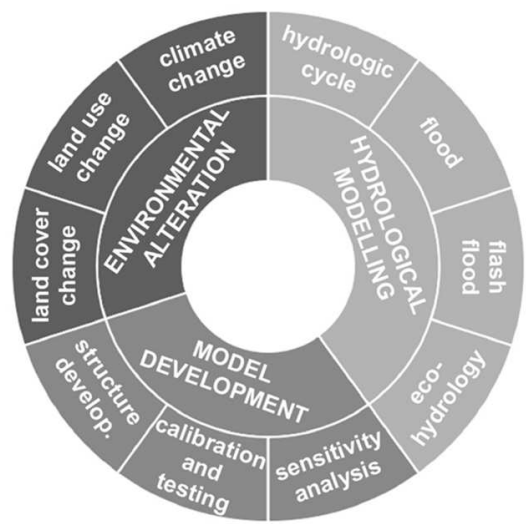

Fig. 7. The main topics of published papers on Scopus web-database during the time period 1998 and 2017

The last group of papers presents the Development of hydrological models, describing the development of new models with an example of application, calibration and testing of the model, and statistical analysis of model sensitivity to input data sets and physical geographic conditions of the research area. For example, Boughton (2004) presented the origin and development of the AWBM model in Australia, and Lehning et al. (2006) described the structure of a new model for mountainous regions based on snow melting information. The importance of the model calibration to study area conditions was presented by $\mathrm{Su}$ et al. (2000) and Cho et al. (2013). Model sensitivity is another important topic, and, e.g., Kalinga and Gan (2006) investigated model sensitivity on gauged and radar rainfall data and Manfreda et al. (2011) determined the model sensitivity to various datasets.

\section{Hydrological models}

In the scope of our investigation, the most frequently employed models were SWAT (used in $15.6 \%$ of the papers), followed by VIC $(6.9 \%)$, HBV $(6.1 \%)$, MIKE SHE (3.8\%) and TOPMODEL (3.2\%). Many models have been frequently used in last few years, e.g., the ten most commonly used models are MOHYSE $(R$ $=+0.92)$, LISFLOOD $(R=+0.91)$, H08 $(R=+0.88)$, GR4J $(R=+0.87)$, HydroGeoSphere $(R=+0.86), \operatorname{HYMOD}(R=+0.83), \operatorname{HYPE}(R=+0.83), \operatorname{MGB}-\mathrm{IPH}(R$ $=+0.74)$, MORDOR $(R=+0.74)$ and Mac-PDM.09 $(R=+0.73)$. A general decline in use was observed for the above-mentioned TOPMODEL $(\mathrm{R}=-0.37)$, followed by WATFLOOD $(R=-0.28)$, TOPLATS $(R=-0.27)$, MODFLOW $(R=-$ $0.26)$, SLURP $(R=-0.25)$, KINEROS $(R=-0.24)$, AGWA $(R=-0.22)$, ADAPT $(R=-0.21)$, MODCOU $(R=-0.21)$ and RHESSys $(R=0.21)$. The application of 
the rest of the most frequently used models stagnated or slightly grew - MIKE $\operatorname{SHE}(\mathrm{R}=-0.05)$, VIC $(\mathrm{R}=+0.1)$, SWAT $(\mathrm{R}=+0.22)$ and $\mathrm{HBV}(\mathrm{R}=+0.33)$.

\section{Cluster analysis}

The arrangement of the hydrological models clustering is depicted in Figure 8, followed by Figure 9, which provides the overview of the percentages of the models' tributes in each cluster, and can be described as follows:

Based on the criterions in section Methods, 756 scientific papers were chosen for analysis. In these papers, 119 hydrological models were applied; in much research more than one model was used. We calculated the total of 999 applications of the models in the papers. Each paper was assigned several attributes of which the year of publication, international cooperation, temporal category (Event, Prediction and Other) and spatial category (Location, Catchment, Regional and Transregional) are relevant for characterisation and interpretation of the clusters. The cluster analysis was conducted by the Chavent et al. (2012) method.

Two clusters

The initial clustering sorts the models into Cluster A and Cluster B. Cluster A includes 18 models that were applied in 243 publications. With 101 models applied in 756 papers, Cluster B is considerably greater. The main difference of these two groups of models is in the percentage of international cooperation $(57.2 \%$ in Cluster A versus $37.7 \%$ in Cluster B), temporal category Event $(31.3 \%$ in Cluster A versus 54.8\% in Cluster B; e.g., HEC-RAS in Sheffer et al. 2008), temporal category Prediction (66.3\% in Cluster A; e.g., VIC in Vetter et al. 2014, versus $41.8 \%$ in Cluster B). Also, there is a prevalence of spatial category Transregional $(47.3 \%)$ in Cluster A (e.g., HBV in Vetter et al. 2014) compared to Cluster B (9.3\%). In contrary, Cluster B shows a greater percentage of spatial category Catchment $(40.5 \%)$, which is only $10.7 \%$ in Cluster A.

Three clusters

Cluster B splits into Cluster B.1 (30 models, 262 applications) and B.2 (71 models, 494 applications). Beside the higher percentage of the spatial category Locality in Cluster A (16.0\% versus $6.7 \%$ in Cluster B), the two clusters do not show any considerable difference.

Four clusters

Cluster B.2 separates to form Cluster B.2.1 (53 models, 370 applications) and Cluster B.2.2 (18 models, 124 applications). There is a prevalence of temporal category Event among the models in Cluster B.2.1 (60.5\%; e.g., GR4J in Ficchi et al. 2016) indicating that in most research, the models were used, for example for case studies. In Cluster B.2.2, the temporal category Prediction shows a greater percentage than the other cluster (52.4\%; e.g., HSAMI in Chen et al. 2017, versus $38.1 \%$; e.g., TOPMODEL in Metcalfe et al. 2017).

Five clusters

Cluster A is divided into Cluster A.1 (8 models, 44 applications) and A.2 (10 models, 199 applications). The clusters differ in multiple aspects. Cluster A.1 includes models that were applied in works published not earlier than 2012. Cluster A.1 also shows a greater percentage of models that were used in international collaboration. The spatial category Transregional is considerably higher in Cluster A.1 


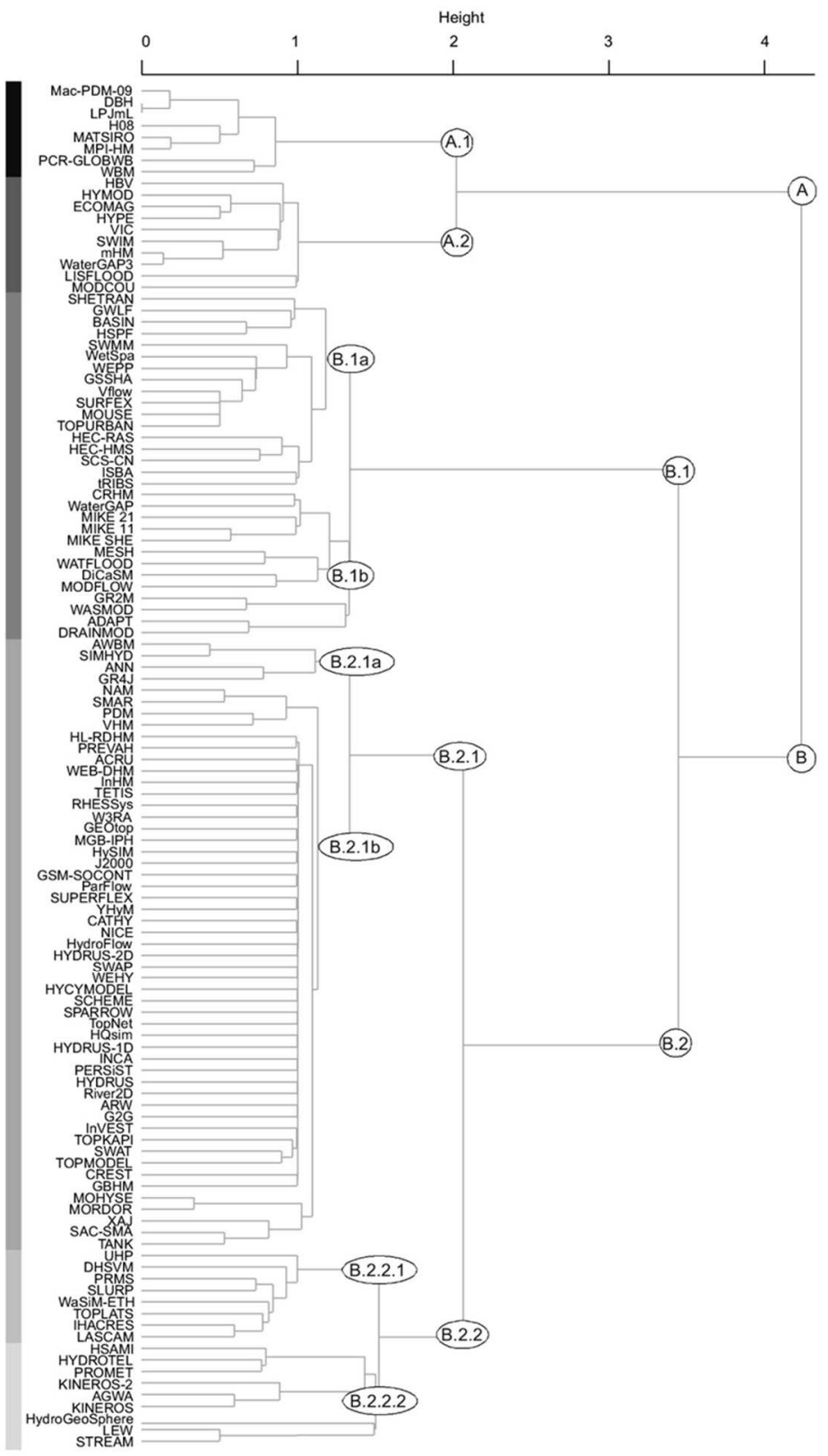

Fig. 8. Dendrogram of model/tool clusters used in chosen hydrological papers published in the Scopus web-database between 1998 and 2017

than in Cluster A.2 (88.6\%; e.g., PCR-GLOBWB in Bosmans et al. 2017; versus $38.2 \%$; e.g., HYPE in Pechlivanidis et al. (2016). This shows, a more frequent use of the models in Cluster A.1 in complex studies focusing on hydrological researches in large areas. On the other hand, the percentage of applications with the spatial category Regional is much lower in Cluster A.1 in comparison with Cluster A.2 
(6.8\% versus 43.7\%; e.g., SWIM in Lobanova et al. 2016). Also, the proportion of spatial category Catchment in Cluster A.1 is lower than in Cluster A.2 (4.5\% versus $12.1 \%$ ). This indicates a prevalence of models applied in smaller scales in Cluster A.2.

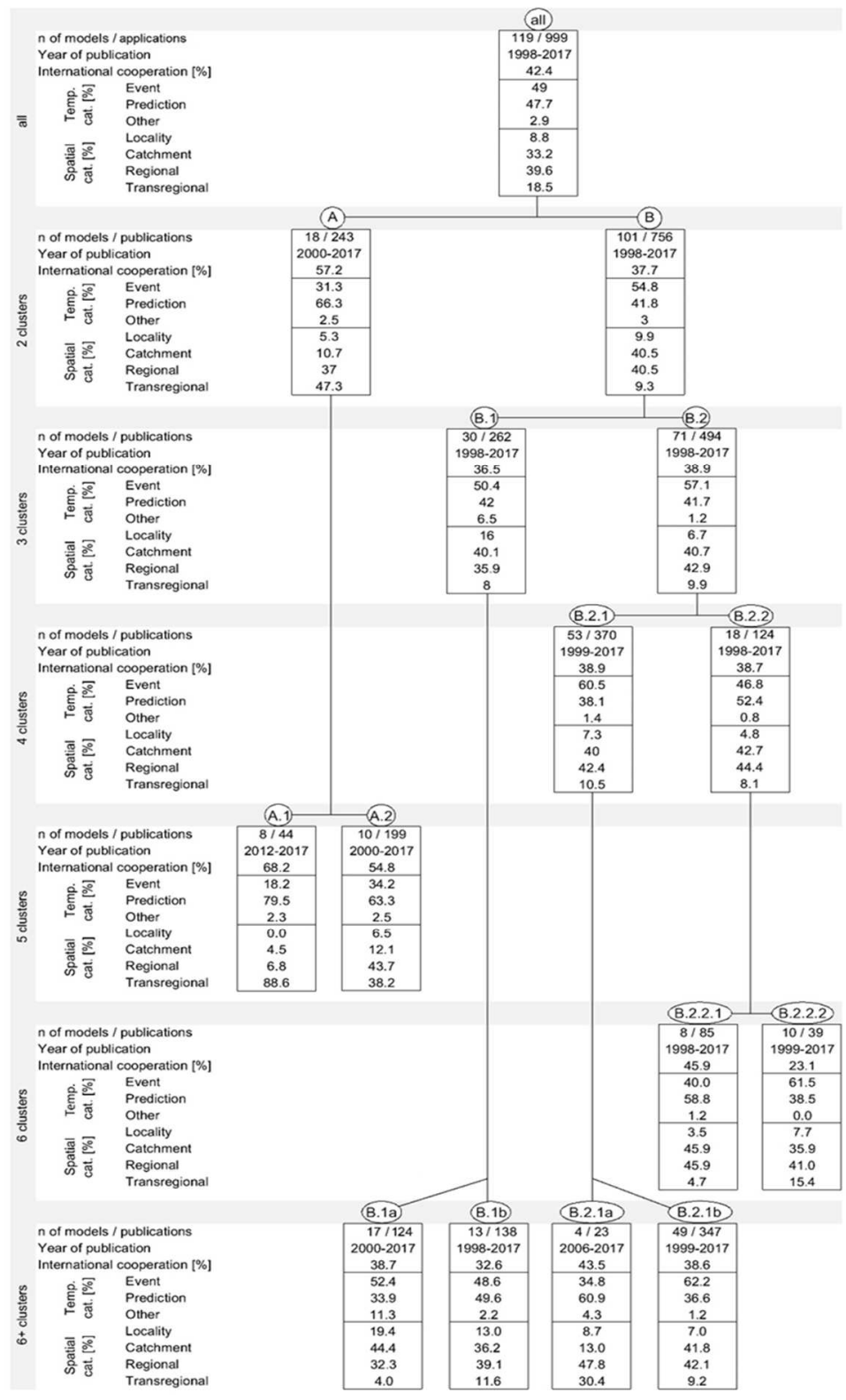

Fig. 9. The characteristics of the models' attributes in each cluster based on the model's applications in chosen hydrological papers published in the Scopus web-database between 1998 and 2017. The first number is number of models in cluster, and the second number presents the total applications of models in cluster. 


\section{Six clusters}

At the level of 6 clusters, Cluster B.2.2 splits into Cluster B.2.2.1 (8 models, 85 applications) and B.2.2.2 (10 models, 39 applications). In Cluster B.2.2.1, the greatest portion of applications is in the temporal category Prediction $(58.8 \%$; e.g., KINEROS-2 in Gal et al. 2017), whereas in Cluster B.2.2.2, the greatest percentage is recorded for spatial category Event (61.5\%; e.g., DHSVM in Zhao et al. 2016). Looking at the spatial categories, the main difference is the higher percentage of category Transregional in Cluster B.2.2.2 (15.4\%; e.g., HYDROTEL in Muerth et al. 2013; versus 4.7\% in Cluster B.2.2.1). The arrangement of the spatial categories outlines that Cluster B.2.2.2 includes mainly models used for studies dealing with greater areas.

Clusters B.1 and B.2.1 include a great number of models (30 and 53). Therefore, both of them have been split into 2 sub-clusters to assess. Cluster B.1 separates into Cluster B.1a (17 models, 124 applications) and B.1b (13 models, 138 applications). Cluster B.1a shows the greatest percentage for temporal category Event (52.3\%; e.g., ISBA in Vincendon et al. 2016). In Cluster B.1b, temporal category Prediction is the most frequent one $(49.3 \%$; e.g., MIKE SHE in Sonnenborg et al. 2015). Cluster B.1b shows a prevalence of spatial categories of greater scales (Regional and Transregional) in comparison with Cluster B.1a.

Cluster B.2.1 splits into clusters B.2.1a (4 models, 23 applications) and B.2.1b (49 models, 347 applications). The main difference is that in Cluster B.2.1a the temporal category Prediction is the most frequent one $(60.9 \%$; e.g., AWBM in Haque et al. 2015). In Cluster B.2.1b temporal category Event shows the greatest percentage (62.2\%; e.g., TETIS in Segura-Beltrán et al. 2016). As for the spatial categories, Cluster B.2.1a includes models with a prevalence of spatial categories Regional and Transregional, whereas in Cluster B.2.1b, there is a considerably greater proportion of the category Catchment.

The cluster analysis also shows that there is a relation between the year of publication and the distribution of percentages over the categories of interest. The initial separation into clusters A and B shows that there is not a significant difference between the two clusters in terms of years of publication $(2000-2017$ in Cluster A, 1998 - 2017 in Cluster B). This influence is more apparent when Cluster A separates to form Custer A.1 and A.2. The former one includes models applied within the period 2012, the latter one during the period 2000 - 2017. Unlike Cluster A.2, Cluster A. 1 has the maximum percentage in temporal category Prediction. The mist frequent spatial category is Transregional. Moreover, the proportion of international cooperation is higher. On the other hand, Cluster A.2 shows the maxima in the categories Event and Region. A very similar situation occurs in the separation of Cluster B.2.1. There is a prevalence of categories Prediction and Transregional in Cluster B.2.1a in comparison with Cluster B.2.1b where the categories Event and Catchment are dominant. However, this arrangement is not always that clearly expressed, as in the example in the splitting of Cluster B.1. Nevertheless, the presented cluster analysis indicates, that in recent years, there has been a shift in the focus of scientific research to greater/global scales. Also, the proportion of international research has increased. These findings can be attributed to the challenges arising from the currently experienced environmental problems associated with climate changes in all parts of the World. 
In terms of the temporal evolution over the investigated period of 1998 to 2017 , the increasing trend was found in cluster A.1 $(R=+0.6)$ and cluster A.2 $(R=+$ $0.5)$. The cluster B.1 $(R=+0.1)$, cluster B.2.1 $(R=+0.24)$ and cluster B.2.2.2 $(R=+0.07)$ stagnated during the period, and the cluster B.2.2.1 $(R=-0.12) \mathrm{qAS}$ slightly decreased. Fig. 10 shows the annual frequency expressed as the percentage of clusters used in the chosen papers during the investigated period. It is apparent that cluster 2 includes two of the most frequently used hydrological models (HBV and VIC), followed by cluster 3 (MIKE SHE) and cluster 4 (SWAT).

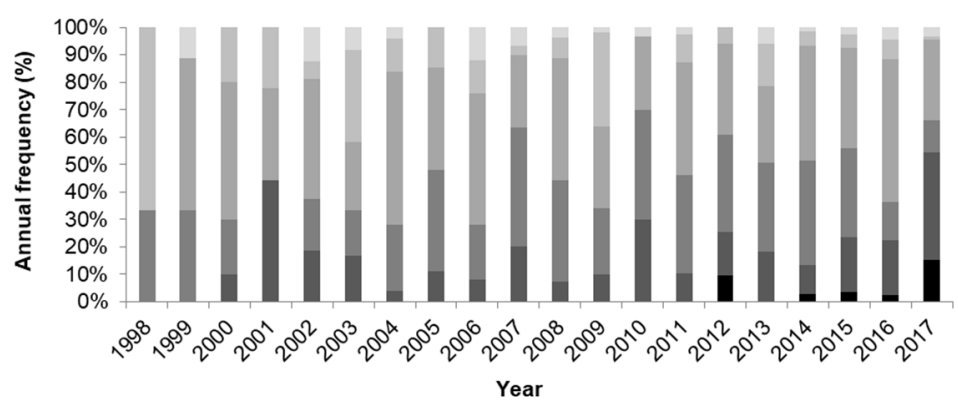

Fig. 10. Annual frequency (in \%) of each of the model/tool clusters used in chosen hydrological papers published in the Scopus web-database between 1998 and 2017 based on the hierarchical classification (colours correspond to clusters of Fig. 8)

\section{DISCUSSION}

The development in the hydrologic modelling was stated by numerous scientists during the last decades (Beven 2001, Lindenschmidt et al. 2005, Silberstein 2006 and Roudier et al. 2015). However, no recent complex analysis has been conducted to detect trends and changes in the field. Piégay et al. (2015) presented an example of such analysis describing the evolution of methods applied within studies in geomorphology, which pointed to fast changes in geomorphological research. This methodology, based on the paper's review connected with statistical analysis of chosen papers' characteristics, is very useful for an evaluation of changes in topics, authorships, models, and temporal and spatial scales of published research during the last decades. Notwithstanding, the ambiguous classification of several papers can affect the results, which presents the vulnerable part of this methodology.

The traditional classification of hydrological models is based on hydrological model parameters and the models' sorting system following the established classifications (in accordance with stochasticity, space and time discretisation). Bízek et al. (2011) presented the comparison of several classifications together with a list of hydrological models and a brief description of the model's applications. Pechlivanidis et al. (2011) added the need of a "model set-up" and the quantification of uncertainty in the model's predictions and highlighted the recent developments in hydrological modelling. A great analysis was also conducted by Salvadore et al. (2015), who has been focused on an assessment of approaches in urban hydrology.

Building upon the methodology by Piégay et al. (2015), this work centered on the quantification of the development of modelling procedures applied in hydrology during the last two decades. The results outline that the field changed quickly 
during the period, which is manifested by an increasing number of published papers, authors and the expansion of new research areas across the world. This growth is probably forced by multiple factors such as economic, social and political. However, the availability of new technology and of quality input data, together with financial support poses the main impulses (Kovár et al. 2001, Kizza et al. 2011, Hailegeorgis and Alferdsen 2015 and Jie et al. 2016). These new capabilities are especially well pronounced in changes of researchers' spatial scales. On the one hand, we are able to target detailed aspects thanks to the higher resolution of spatially-distributed data (Salvadore et al. 2015). On the other hand, hydrological models can be applied to much larger spatial scales, as on a continental or even a global level. This permits the study of the global consequences of the hydrological cycle (Brakenridge et al. 2012, Sperna Weiland et al. 2012, Decharme et al. 2014 and Khaki et al. 2017). In accordance with the increasing proportion of research at a continental or world level, the percentage of international cooperation in research activities has been increasing.

As for the papers' topics, the results revealed that most of the new research has focused on the predictions of the future evolution of the hydrological cycle corresponding to other works (Tague and Band 2001, Danihlík et al. 2004, Cho and Olivera, 2009, Alfieri et al. 2011, Björn et al. 2015, etc.). We also found that the proportion of papers focused on "Events" (case studies) has reduced, as the papers focusing on the flood modelling (the flood reconstruction) are overtaken by the hydro-climatological topics on the planetary level. In this context, the land use changes in all scales are a frequently discussed topic and very often, the hydrological models pervade the group of erosion models in this subject matter. That's why some of the hydrological models can be also classified as erosion models, e.g., the SWAT model. The last of the great topics is the development and the setting of hydrological models in general, which contains the model design, calibration and testing (validation and verification) and the sensitivity analysis. Danihlík et al. (2004), El-Nasr et al. (2005), Schneiderman et al. (2007), Viney et al. (2009), and Pechlivanidis et al. (2011) compared several hydrological models and mentioned the need for the accurate model's setting, and the importance of the "set up" part was emphasized in all analysed papers.

\section{CONCLUSIONS}

In this study, we focused on a quantitative and qualitative analysis of scientific papers concerning hydrological modelling to reveal the evolution of the field during the period $1998-2017$. Beside several partial analyses, such a complex study for SCOPUS web-database has not been conducted in a similar way. A similar methodology as that used by Piégay et al. (2015) was applied in this study. Almost 760 published papers in the Scopus web database were analysed to characterize trends in hydrological research.

Our research reveals the rapid development of the field as manifested by the rising diversity of research localities across the world (Fig. 3), together with the expanding list of used models (371 hydrological models were identified within the 756 papers), which corresponds to an increasing number of authors (Figs. 3 and 4) and countless research topics addressing the physical, mathematical, methodological, biochemical, environmental, social and economic behavioural aspects of hydrological processes (Fig. 7). This multidisciplinarity of the field demonstrates the 
need for cooperation among scientists not only from different countries or continents (almost $50 \%$ of contemporary papers were created within the international cooperation) but also from other scientific fields (e.g. IT, agriculture, engineering and economics). From a geographical point of view, the diversity of the papers' countries of origin has been growing. Nevertheless, we identified three global centres of hydrological research - North America, Europe and South-East Asia (Fig. 2).

Based on our classification system of different spatial and temporal categories, we identified six clusters/groups of hydrological models. Additionally, $78 \%$ of the models were utilized for 'catchment', 'regional' or 'trans-regional' research of different temporal scales. The remaining hydrological models do not show significant relationships with any spatial or temporal category. We detected three models employed in $28.5 \%$ of the investigated papers - SWAT, VIC and HBV. These models address hydrological processes of various scales and represent characteristic approaches of research in hydrological modelling.

It should be noted that our results are influenced by the fact that we focused on papers from only one web database, Scopus (with the largest amount of suitable papers). Extending our research to other databases, such as Science Direct and Web of Science, would provide a different dataset to be analysed. Thus, slightly modified results could be obtained. The next challenge in this line of inquiry might be to compare information acquired from more web databases and to explore a wider range of papers to extend our database.

To conclude, hydrological modelling is becoming more accessible for other sciences. Technological progress and the narrowly specialized research demand interdisciplinary cooperation of scientists and the introduction of new approaches. The advancing trans-national cooperation and global exchange of information will probably erase the differences among various regions.

This study was supported by the Specific Research project at Masaryk University (MUNI/A/1251/2017, Integrated research of environmental changes in the landscape sphere III). The authors thank the agency for their research support.

\section{REFERENCES}

ALAOUI, A., WILLIMANN, E., JASPER, K., FELDER, G., HERGER, F., MAGNUSSON, J., WEINGARTNER, R. (2014). Modelling the effects of land use and climate changes on hydrology in the Ursern Valley, Switzerland. Hydrological Processes, 28, 3602-3614.

ALFIERI, L., THIELEN, J., PAPPENBERGER, F. (2011). Ensemble hydro-meteorological simulation for flash flood early detection in southern Switzerland. Journal of Hydrology, 424-425, 143-153.

AL-HAMDAN, O. Z., HERNANDEZ, M., PIERSON, F. B., NEARING, M. A., WILLIAMS, C. J., STONE, J. J., BOLL, J., WELTZ, M. A. (2015). Rangeland hydrology and erosion model (RHEM) enhancements for applications on disturbed rangelands. Hydrological Processes, 29, 445-457.

BADAR, B., ROMSHOO, S. A., KHAN, M. A. (2013). Modelling catchment hydrological responses in a Himalayan Lake as a function of changing land use and land cover. Journal of Earth System Science, 122, 433-449.

BECKER, A., SERBAN, P. (1990). Hydrological models for water-resources system design and operation. Operational Hydrology Report No. 34. Geneva (WMO). 
BEIGHLEY, R. E., DUNNE, T., MELACK, J. M. (2005). Understanding and modelling basin hydrology: interpreting the hydrogeological signature. Hydrological Processes, 19, 1333-1353.

BENJANKAR, R., EGGER, G., JORDE, K., GOODWIN, P., GLENN, N. F. (2011). Dynamic floodplain vegetation model development for the Kootenai River, USA. Journal of Environmental Management, 92, 3058-3070.

BEVEN, K. (2001). Rainfall-runoff modelling: the primer. Chichester (Wiley).

BEVEN, K. (2012). Rainfall-runoff modelling: the primer, second ed. Chichester (Wiley).

BEVEN, K., LAMB, R., QUINN, P., ROMANOWICZ, R., FREER, J. (1995). TOPMODEL. In Singh, V. P., ed. Computer models of watershed hydrology. Boulder (Water Resources Publications), pp. 627-668.

BÍZEK, V., FOLTÝN, I., HELOVÁ, S., JENÍČEK, M., KOBLÍŽKOVÁ, E., KODEŠOVÁ, R., MERTL, J., NESMĚRÁK, I., NONDEK, L., RATINGER, T. (2011). Aplikace modelu v oblasti životního prostredí. Praha (CENIA).

BJÖRN, G., KAIL, J., RADINGER, J., SCHRÖDER, M., KIESEL, J., HERING, D., WOLTER, C., FOHRER,N. (2015). Eco-hydrologic model cascades: simulating land use and climate change impacts on hydrology, hydraulics and habitats for fish and macroinvertebrates. Science of the Total Environment, 533, 542-556.

BOSMANS, J. H. C., Van BEEK, L. P. H., SUTANUDJAJA, E. H., BIERKENS, M. F. P. (2017). Hydrological impacts of global land cover change and human water use. Hydrology and Earth System Sciences, 21, 5603-5626.

BORMANN, H., BREUER, L., GRÄFF, T., HUISMAN, J. A., CROKE, B. (2009). Assessing the impact of land use change on hydrology by ensemble modelling (LUCHEM) IV: model sensitivity to data aggregation and spatial (re-)distribution. Advances in Water Resources, 32, 171-192.

BOUGHTON, W. (2004). The Australian water balance model. Environmental Modelling \& Software, 19, 943-956.

BRAKENRIDGE, G. R., COHEN, S., KETTNER, A. J., DE GROEVE, T., NGHIEM, S. V., SYVITSKI, J. P. M., FEKETE, B. M. (2012). Calibration of satellite measurements of river discharge using a global hydrology model. Journal of Hydrology, 475, 123-136.

BUCHANAN, B., EASTON, Z. M., SCHNEIDER, R. L., WALTER, M. T. (2013). Modelling the hydrologic effects of roadside ditch networks on receiving waters. Journal of Hydrology, 486, 293-305.

BUTTS, M., DREWS, M., LARSEN, M. A. D., LERER, S., RASMUSSEN, S. H., GROOS, J., OVERGAARD, J., REFSGAARD, J. C., CHRISTENSEN, O. B., CHRISTENSEN, J. H. (2014). Embedding complex hydrology in the regional climate system Dynamic coupling across different modelling domains. Advances in Water Resources, 74, 16-184.

CHAVENT, M., KUENTZ-SIMONET, V., LIQUET, B., SARACCO, J. (2012). ClustOfVar: an R package for the clustering of variables. Journal of Statistical Software, 50(13), 1-16.

CHEN, J., BRISSETTE, F. P., LIU, P., XIA, J. (2017). Using raw regional climate model outputs for quantifying climate change impacts on hydrology. Hydrological Processes, 31, 4398-4413.

CHO, H., OLIVERA, F. (2009). Effect of the spatial variability of land use, soil type, and precipitation on streamflows in small watersheds. Journal of the American Water Resources Association, 45 (3), 673-686.

CHO, J., BOSCH, D., VELLIDIS, G., LOWRANCE, R., STRICKLAND, T. (2013). Multisite evaluation of hydrology component of SWAT in the coastal plain of southwest Georgia. Hydrological Processes, 27, 1691-1700.

COLLIER, C. G. (2007). Flash flood forecasting: what are the limits of predictability? Journal of The Royal Meteorological Society, 133, 3-23.

COUSTAU, M., BOUVIER, C., BORRELL-ESTUPINA, V., JOURDE, H. (2012). Flood modelling with a distributed event-based parsimonious rainfall-runoff model: case of 
the karstic Lez river catchment. Natural Hazards and Earth System Sciences, 12, 11191133.

DAŇHELKA, J., KREJČÍ, J., ŠÁLEK, M., ŠERCL, P., ZEZULÁK, J. (2003). Posouzení vhodnosti aplikace srážko-odtokových modelù s ohledem na simulaci povodñových stavu pro lokality na území ĆR. Praha (CZU).

DANIHLÍK, R., HLAVČOVÁ, K., KOHNOVÁ, S., PARAJKA, J., SZOLGAY, J. (2004). Scenarios of the change in the mean annual and monthly runoff in the Hron Basin. Journal of Hydrology and Hydromechanics, 52, 291-302.

DECHARME, B., ALKAMA, R., DOUVILle, H., BECKER, M., CAZENAVE, A. (2014). Global evaluation of the ISBA-TRIP continental hydrological system. Part II: Uncertainties in river routing simulation related to flow velocity and groundwater storage. Journal of Hydrometeorology, 11, 601-617.

EL-NASR, A. A., ARNOLD, J. G., FEYEN, J., BERLAMONT, J. (2005). Modelling the hydrology of a catchment using a distributed and a semi-distributed model. Hydrological Processes, 19, 573-587.

EMAM, A. R., KAPPAS, M., HOSSEINI, S. Z. (2015). Assessing the impact of climate change on water resources, crop production and land degradation in a semi-arid river basin. Hydrology Research, 46, 854-870.

FARES, A., AWAL, R., MICHAUD, J., CHU, P.-S., FARES, S., KODAMA, K., ROSENER, M. (2014). Rainfall-runoff modelling in a flashy tropical watershed using the distributed HL-RDHM model. Journal of Hydrology, 519, 3436-3447.

FICCHI, A., PERRIN, C., ANDRÉASSIAN, V. (2016). Impact of temporal resolution of inputs on hydrological model performance: an analysis based on 2400 flood events. Journal of Hydrology, 538, 454-470.

FURUSHO, C., CHANCIBAULT, K., ANDRIEU, H. (2013). Adapting the coupled hydrological model ISBA-TOPMODEL to the long-term hydrological cycles of suburban rivers: evaluation and sensitivity analysis. Journal of Hydrology, 485, 139-147

GAL, L., GRIPPA, M., HIERNAUX, P., PONS, L., KERGOAT, L. (2017). The paradoxical evolution of runoff in the pastoral Sahel: Analysis of the hydrological changes over the Agoufou watershed (Mali) using the KINEROS-2 model. Hydrology and Earth System Science, 21, 4591-4613.

GARAMBOIS, P. A., ROUX, H., LARNIER, K., CASTAINGS, W., DARTUS, D. (2013). Characterization of process-oriented hydrologic model behaviour with temporal sensitivity analysis for flash floods in Mediterranean catchments. Hydrology and Earth System Science, 17, 2305-2322.

GAYATHRI, K. D., GANASRI, B. P., DWARAKISH, G. S. (2015). A review on hydrological models. Aquatic Procedia, 4, 1001-1007.

GOEBEL, P. C., PREGITZER, K. S., PALIK, B. J. (2012). Influence of flooding and landform properties on riparian plant communities in an old-growth northern hardwood watershed. Wetlands, 32, 679-691.

GUSE, B., KAIL, J., RADINGER, J., SCHRÖDER, M., KIESEL, J., HERING, D., WOLTER, C., FOHRER, N. (2015). Eco-hydrologic model cascades: simulating land use and climate change impacts on hydrology, hydraulics and habitats for fish and macroinvertebrates. Science of the Total Environment, 533, 542-556.

HAILEGEORGIS, T. T., ALFREDSEN, K. (2015). Comparative evaluation of performances of different conceptualisations of distributed HBV runoff response routines for prediction of hourly streamflow in boreal mountainous catchments. Hydrology Research, 46, 607-628.

HAQUE, M., RAHMAN, A., HAGARE, D., KIBRIA, G., KARIM, F. (2015). Estimation of catchment yield and associated uncertainties due to climate change in a mountainous catchment in Australia. Hydrological Processes, 29, 4339-4349.

HERNÁNDEZ, J.-H., PADILLA, F., JUNCOSA, R., VELLANDO, P.R., FERNÁNDEZ, A. (2012). A numerical solution to integrated water flows: application to the flooding of an open pit mine at the Barcés river catchment - La Coruña, Spain. Journal of Hydrology, 472-473, 328-339. 
HLAVČOVÁ, K., HOLLOVÁ, J., KOHNOVÁ, S. (2007). The development of rainfallrunoff system for the Poprad River basin. Acta Hydrologica Slovaca, 8(1), 56-66.

HUGHES, D. A. (2009). Simulating the hydrology and total dissolved solids (TDS) of an ephemeral river in South Africa for environment determinations. River Research and Applications, 25, 850-860.

JHA, M. K., GASSMAN, P. W. (2014). Changes in hydrology and streamflow as predicted by a modelling experiment forced with climate models. Hydrological Processes, 28, 2772-2781.

JIE, M.-X., CHEN, H., XU, C.-Y., TAO, X. (2016). A comparative study of different objective functions to improve the flood forecasting accuracy. Hydrology Research, 47, 718-735.

KALINGA, O. A., GAN, T. Y. (2006). Semi-distributed modelling of basin hydrology with radar and gauged precipitation. Hydrological Processes, 20, 3725-3746.

KHAKI, M., AIT-EL-FQUIH, B., HOTEIT, I., FOROOTAN, E., AWANGE, J., KUHN, M. (2017). A two-update ensemble Kalman filter for land hydrological data assimilation with an uncertain constraint. Journal of Hydrology, 555, 447-462.

KIZZA, M., RODHE, A., XU, C.-Y., NTALE, H. (2011). Modelling catchment inflows into Lake Victoria: uncertainties in rainfall-runoff modelling for the Nzoia River. $H y$ drological Sciences Journal, 56, 1210-1226.

KOČICKÝ, D., HORVÁT, O., HLAVČOVÁ, K., SZOLGAY, J., KOHNOVÁ, S., TEGELHOFFOVÁ, M. (2008). Modelling impact of changes in hydro-ecological complexes on the runoff in the Hornád River basin. Acta Hydrologica Slovaca, 9, 218-227.

KOVÁR̆, K., NACHTNEBEL, H. P. (1996). HydroGIS96: application of geographic information systems in hydrology and water resources management: Proceedings of the Vienna Conference, April 1996. Vienna (IAHS Publication 235).

KOVÁŘ, P., CUDLÍN, P., KORYTAR, M., ZEMEK, F., HERMAN, M. (2001). Comparative study of water balance on the experimental catchments Vseminka and Drevnice. Rostlinná Výroba, 47, 260-266.

KULHAVÝ, Z, KOVÁR̆, P. (2002). Využití modelu hydrologické balance pro malá povodí. Praha (VƯMOP).

LEHNING, M., VÖLKSCH, I., GUSTAFSSON, D., NGUYEN, T. A., STÄHLI, M., ZAPPA, M. (2006). ALPINE3D: a detailed model of mountain surface processes and its application to snow hydrology. Hydrological Processes, 20, 2111-2128.

LINDENSCHMIDT, K. E., FLEISCHBEIN, K., PETROW, T., VOROGUCHYN, S., THEOBALD, S., MERZ, B. (2005). Model system development and uncertainty for the provisionary management of extreme floods in large river basins. Advances in Geosciences, 5, 99-104.

LOBANOVA, A., KOCH, H., LIERSCH, S., HATTERMANN, F. F., KRYSANOVA, V. (2016). Impacts of changing climate on the hydrology and hydropower production of the Tagus River basin. Hydrological Processes, 30, 5039-5052.

MAALIM, F. K., MELESSE, A. M., BELMONT, P., GRAN, K. B. (2013). Modelling the impact of land use changes on runoff and sediment yield in the Le Sueur watershed, Minnesota using GeoWEPP. Catena, 107, 35-45.

MAKEL, M., TURBEK, J. (2008). Terminological monological dictionary - Hydrology. Bratislava (Ministry of Environment of the Slovak Republic).

MANFREDA, S., LACAVA, T., ONORATI, B., PERGOLA, N., DI LEO, M., MARGIOTTA, M. R., VALERIO, T. (2011). On the use of AMSU-based products for the description of soil water content at basin scale. Hydrology and Earth System Sciences, 15, 2839-2852.

METCALFE, P., BEVEN, K., HANKIN, B., LAMB, R. (2017). A modelling framework for evaluation of the hydrological impacts of nature-based approaches to flood risk management, with application to in-channel interventions across a $29-\mathrm{km}^{2}$ scale catchment in the United Kingdom. Hydrological Processes, 31, 1734-1748. 
MUERTH, M. J., GAUVIN ST-DENIS, B., RICARD, S., VELÁZQUEZ, J. A., SCHMID, J., MINVILLE, M., CAYA, D., CHAUMONT, D., LUDWIG, R., TURCOTTE, R. (2013). On the need for bias correction in regional climate scenarios to assess climate change impacts on river runoff. Hydrology and Earth System Sciences, 17, 1189-1204.

NUNES, J. P., SEIXAS, J., KEIZER, J. J., FORREIRA, A. J. D. (2009). Sensitivity of runoff and soil erosion to climate change in two Mediterranean watersheds. Part II: assessing impacts from changes in storm rainfall, soil moisture and vegetation cover. Hydrological Processes, 23, 1212-1230.

O'NEIL, R. V., KRUMMEL, J. R., GARDNER, R. H., SUGIHARA, G., JACKSON, B., DEANGELIS, D. L., MILNE, B. T., TURNER, M. G., ZYGMUNT, B., CHRISTENSEN, S. W., DALE, V. H., GRAHAM, R. L. (1988). Indices of landscape pattern. Landscape. Ecology, 1, 153-162.

PARAJKA, J., BEZAK, N., BURKHART, J., HAUKSSON, B., HOLKO, L., HUNDECHA, Y., JENICEK, M., KRAJCI, P., MANGINI, W., MOLNAR, P., RIBOUST, P., RIZZI, J., SENSOY, A., THIREL, G., VIGLIONE, A. (2018). MODIS snowline elevation changes during snowmelt runoff events in Europe. Journal of Hydrology and Hydromechanics, 67, 1-9.

PIÉGAY, H., KONDOLF, M. G., MINEAR, T. J., VAUDOR, L. (2015). Trends in publications in fluvial geomorphology over two decades: A truly new era in the discipline owing to recent technological revolution? Geomorphology, 248, 489-500.

PECHLIVANIDIS, I. G., JACKSON, B. M., McINTYRE, N. R., WHEATER, H. S. (2011). Catchment scale hydrological modelling: a review of model types, calibration approaches and uncertainty analysis methods in the context of recent developments in technology and applications. Global NEST Journal, 13, 193-214.

PECHLIVANIDIS, I. G., ARHEIMER, B., DONNELLY, C., HUNDECHA, Y., HUANG, S., AICH, V., SAMANIEGO, L., ELSNER, S., SHI, P. (2016). Analysis of hydrological extremes at different hydro-climatic regimes under present and future conditions. Climatic Change, 141, 467-481.

PEKÁROVÁ, P., MIKLÁNEK, P. (2014). Flash flood on 21. 07. 2014 in the Vrátna valley. Acta Hydrologica Slovaca, 15, 3-12.

ROUDIER, P., ANDERSSON, J. C. M., DONNELLY, C., FEYEN, L., GREUELL, W., LUDWIG, F. (2015). Projections of future floods and hydrological droughts in Europe under a $+2^{\circ} \mathrm{C}$ global warming. Climatic Change, 135, 341-355.

SALVADORE, E., BRONDERS, J., BATELAAN, O. (2015). Hydrological modelling of urbanized catchments: A review and future directions. Journal of Hydrology, 529, 6281.

SANGATI, M., BORGA, M., RABUFFETTI, D., BECHINI, R. (2009). Influence of rainfall and soil properties spatial aggregation on extreme flash flood response modelling: An evaluation based on the Sesia river basin, North Western Italy. Advances in Water Resources, 32, 1090-1106.

SCHNEIDERMAN, E. M., STEENHUIS, T. S., THONGS, D. J., EASTON, Z. M., ZION, M. S., NEAL, A. L., MENDOZA, G. F., WALTER, M. T. (2007). Incorporating variable source area hydrology into a curve-number-based watershed model. Hydrological Processes, 21, 3420-3430.

SEGUURA-BELTRÁN, F., SANCHIS-IBOR, C., MORALES-HERNÁNDEZ, M., GONZÁLEZ-SANCHIS, M., BUSSI, G., ORITZ, E. (2016). Using post-flood surveys and geomorphologic mapping to evaluate hydrological and hydraulic models: the flash flood of the Girona River (Spain) in 2007. Journal of Hydrology, 541(A), 310-329.

SHARIF, H. O., YATES, D., ROBERTS, R., MUELLER, C. (2006). The use of an automated nowcasting system to forecast flash floods in an urban watershed. The Journal of Hydrometeorology, 7, 190-202.

SHEFFER, N. A., RICO, M., ENZEL, Y., BENITO, G., GRODEK, T. (2008). The Palaeoflood record of the Gardon River, France: a comparison with the extreme 2002 flood event. Geomorphology, 98(1-2), 71-83. 
SILBERSTEIN, R. P. (2006). Hydrological models are so good, do we still need data? Environmental Modelling and Software, 21, 1340-1352.

ŠINKA, K., MUCHOVÁ, Z., KONC, L. (2015). Geografické informačné systémy v priestorovom plánovaní, Nitra (Slovak University of Agriculture in Nitra).

SONNENBORG, T. O., SEIFER, D., REFSGAARD, J. C. (2015). Climate model uncertainty versus conceptual geological uncertainty in hydrological modelling. Hydrology and Earth System Science, 19, 3891-3901.

SPERNA WEILAND, F. C., Van BEEK, L. P. H., WEERTS, A. H., BIERKENS, M. F. P. (2012). Extracting information from an ensemble of GCMs to reliably assess future global runoff change. Journal of Hydrology, 412-413, 66-75.

SU, M., STOLTE, W. J., KAMP, G. (2000). Modelling Canadian prairie wetland hydrology using a semi-distributed streamflow model. Hydrological Processes, 14, 2405-2422.

SZOLGAY, J., GAÁL, L., BACIGÁL, T., KOHNOVÄ, S., HLAVČOVẢ, K., VÝLETA, R., PARAJKA, J., BLÖSCHL, G. (2016). A regional comparative analysis of empirical and theoretical flood peak-volume relationships. Journal of Hydrology and Hydromechanics, 64, 367-381.

SZOLGAYOVÁ, E., ARLT, J., BLÖSCHL, G., SZOLGAY, J. (2014). Wavelet based deseasonalization for modelling and forecasting of daily discharge series considering long range dependence. Journal of Hydrology and Hydromechanics, 62, 24-32.

TAGUE, C. L., BAND, L. E. (2001). Evaluating explicit and implicit routing for watershed hydro-ecological models of forest hydrology at the small catchment scale. Hydrological Processes, 15, 1415-1439.

UNUCKA, J. (2014). Environmentální modelování I. Ostrava (Ostravská univerzita v Ostravě).

VETTER, T., HUANG, S., AICH, V., YANG, T., WANG, X., KRYSANOVA, V., HATTERMANN, F. (2014). Multi-model climate impact assessment and intercomparison for three large-scale river basins on three continents. Earth System Dynamics, 5, 849-900.

VINCENDON, B., ÉDOUARD, S., DEWAELE, H., DUCROQ, V., LESPINAS, F., DELRIEU, G., ANQUETIN, S. (2016). Modelling flash floods in southern France for road management purposes. Journal of Hydrology, 541(A), 190-205.

VINEY, R., BORMANN, H., BREUER, L., BRONSTERT, A., CROKE, B. F. W., FREDE, H., GRÄFF, T., HUBRECHTS, L., HUISMAN, J. A., JAKEMAN, A. J., KITE, G. W., LANINI, J., LEAVESLEA, G., LETTENMAIER, D. P., LINDSTRÖM, G., SEIBERT, J., SIVAPALAN, M., WILLEMS, P. (2009). Assessing the impact of land use change on hydrology by ensemble modelling (LUCHEM) II: ensemble combinations and predictions. Advances in Water Resources, 32, 147-158.

WHEATER, H. S., SOROOSHIAN, S., SHARMA, K. D. (2008). Hydrological modelling in arid and semi-arid areas. Cambridge (Cambridge University Press).

WHEATER, H. S., EVANS, E. P. (2009). Land use, water management and future flood risk. Land Use Policy, 26, 251-264.

WHITEHEAD, P. G., JIN., L., CROSSMAN, J., COMBER, S., JOHNES, P. J., DALDORPH, P., FLYNN, N., COLLINS, A. L., BUTTERFIEDL, D., MISTRY, R., BARDON, R., POPE, L., WILLOWS, R. (2014). Distributed and dynamic modelling of hydrology, phosphorus and ecology in the Hampshire Avon and Blashford Lakes: evaluating alternative strategies to meet WFD standards. Science of the Total Environment, 481, 157-166.

YEVJEVICH, V. (1987). Stochastic models in hydrology. Stochastic Hydrology and Hydraulics, 1, 17-36.

ZANON, F., BORGA, M., ZOCCATELLI, D., MARCHI, L., GAUME, E., BONNIFAIT, L., DELRIEU, G. (2010). Hydrological analysis of a flash flood across a climatic and geologic gradient: The September 18, 2007 event in Western Slovenia. Journal of Hydrology, 394, 182-197.

ZENG, Q., CHEN, H., XU, C.-Y., JIE, M.-X., HOU, Y.-K. (2016). Feasibility and uncertainty of using conceptual rainfall-runoff models in design flood estimation. Hydrology Research, 47, 701-717. 
ZHAO, G., GAO, H., CUO, L. (2016). Effects of urbanization and climate change on peak flows over the San Antonio River basin, Texas. American Meteorological Society, 17, 2371-2389.

David Honek, Martin Caletka, Monika Šulc Michalková

\section{RETROSPEKTÍVNA ANALÝZA PUBLIKOVANÝCH \\ HYDROLOGICKÝCH VÝSKUMOV: MODELY, TRENDY \\ A GEOGRAFICKÝ ASPEKT HYDROLOGICKÉHO MODELOVANIA V POSLEDNÝCH DVOCH DEKÁDACH}

Táto práca si kladie za ciel' zhodnotit' vývoj v oblasti hydrologického modelovania za posledných dvadsat' rokov s použitím kvantitatívnych a kvalitatívnych analýz. Analyzovaných bolo 756 vedeckých článkov, ktoré boli vyhl'adané pomocou webovej databázy SCOPUS. Vybrané články pokrývajú časové obdobie 1998 až 2017 a prezentujú rôznorodé práce využívajúce 371 hydrologických modelov. Štatistické spracovanie údajov je založené na metodike Piégay et al. (2015).

Výsledky dokumentujú rýchly vývoj v tejto oblasti výskumu, čo dokladá neustále sa zvyšujúci počet článkov a tiež aplikovaných hydrologických modelov. Hydrologické modely možno rozdelit' pomocou mnohých klasifikácií. V tomto článku je prezentovaný nový prístup delenia modelov na základe charakteristík ich jednotlivých aplikácií v rámci vybraného súboru článkov a zároveň analyzované súčasné trendy vývoja disciplíny. Rastúci počet nových autorov sa venuje vel'kému množstvu tém - od matematického a fyzikálneho modelovania prírodných procesov, cez environmentálne a biochemické štúdie, až po dôsledky zmien hydrologických procesov na sociálne a ekonomické správanie spoločnosti. Trendom je rastúca interdisciplinarita hydrologického modelovania a medzinárodné tímy. Za hlavné centrá výskumu možno považovat' Severnú Ameriku, Európu a juhovýchodnú Áziu.

Klasifikačná metodika vychádzajúca $\mathrm{z}$ rôznych priestorových a časových parametrov aplikovaných modelov odhalila šest' hlavných skupín/klastrov. Modely sú najčastejšie aplikované v mierke povodí a regiónov, pracujú s rôznym časovým rozlíšením, ale v posledných rokoch pribúdajú práce venované rozsiahlym oblastiam s rozlohou viac ako 10000 $\mathrm{km}^{2}$, čo súvisí s rastúcim záujmom o štúdium dôsledkov klimatických a environmentálnych zmien. Tri najčastejšie používané modely sú SWAT, VIC a HBV, ktoré sa objavili v $28,5 \%$ článkov.

Záverom možno povedat', že hydrologické modelovanie je dynamicky sa vyvíjajúce odvetvie. Významnou hybnou silou sú dostupné technológie na spracovanie vel'kých objemov kvalitných dát. Všetky tieto aspekty umožňujú aplikáciu náročných postupov, vd’aka ktorým je možné simulovat' zložité prírodné procesy v rôznych časovo-priestorových mierkach. V posledných rokoch sa zvyšuje počet prác zameraných na kontinentálne až globálne modelovanie. 
